\title{
ANALISIS KOMPARASI MODEL PREDIKSI FINANCIAL DISTRESS ALTMAN, SPRINGATE, GROVER DAN OHLSON PADA PERUSAHAAN MANUFAKTUR YANG TERDAFTAR DI BURSA EFEK INDONESIA PERIODE 2011-2013
}

\author{
Rini Tri Hastuti \\ Fakultas Ekonomi Universitas Tarumanagara \\ Email: rcouture7272@yahoo.com
}

\begin{abstract}
This study purpose to determine the most accurate bankruptcy prediction model in order to suitable for use in its application to manufacturing companies in Indonesia, and to determine whether there is a difference Altman models with Springate models, Altman models with Grover models, and Altman models with Ohlson models. Scope of the study is limited to manufacturing industry companies listed on the Indonesia Stock Exchange during the years 2011-2013. This study comparing four bankruptcy prediction model by using statistic descriptive analysis techniques also Kolmogorov-Smirnov normality test and paired test analysis techniques sample t-test with the help of SPSS program. Conclusion of this study showed significant differences between the models Altman with Springate models, Altman models with Grover models, and Altman models with Ohlson models. And the highest level of accuracy achieved by the Grover models.
\end{abstract}

Keywords: Financial Distress, Kolmogorov-Smirnov, Predictions Model

\begin{abstract}
Abstrak: Penelitian Tujuan ini untuk menentukan model prediksi kebangkrutan yang paling akurat untuk cocok untuk digunakan dalam aplikasi untuk perusahaan manufaktur di Indonesia, dan untuk menentukan apakah ada model perbedaan Altman dengan model Springate, model Altman dengan model Grover, dan Altman model dengan model Ohlson. Lingkup penelitian ini terbatas untuk perusahaan manufaktur industri yang terdaftar di Bursa Efek Indonesia selama tahun 2011-2013. Penelitian ini membandingkan model prediksi empat kebangkrutan dengan menggunakan teknik statistik deskriptif analisis juga uji normalitas Kolmogorov-Smirnov dan dipasangkan analisis uji teknik sample t-test dengan bantuan program SPSS. Kesimpulan dari penelitian ini menunjukkan perbedaan yang signifikan antara model Altman dengan model Springate, model Altman dengan model Grover, dan model Altman dengan model Ohlson. Dan tingkat akurasi tertinggi dicapai oleh model Grover.
\end{abstract}

Kata kunci: Financial Distress, Kolmogorov-Smirnov, Prediksi Model

\section{PENDAHULUAN}

Tahun 2015 mendatang, Indonesia akan menghadapi pasar bebas ASEAN yang tentunya akan membuat persaingan bisnis menjadi semakin ketat lagi. Perusahaan-perusahaan yang ada di Indonesia harus mampu bersaing untuk menghadapi semua kondisi dan keadaan tersebut diatas, sebab bila tidak, ketidaksiapan dan ketidakmampuan untuk bersaing akan menyebabkan aktivitas bisnis menjadi buruk dan bila perusahaan tidak dapat bertahan, akan membuat kondisi keuangan perusahaan menjadi tidak sehat (financial distress) dan yang terparah adalah akan mengalami kebangkrutan. 
Segala macam tindakan pencegahan perlu dilakukan oleh perusahaan agar dapat terhindar dari kebangkrutan, salah satunya adalah dengan melakukan deteksi dini. Menurut Hartoyo (2013), analisa ini dilakukan untuk memperoleh peringatan awal akan terjadinya kebangkrutan. Semakin awal tanda-tanda kebangkrutan tersebut diketahui, semakin baik untuk pihak manajemen perusahaan, karena dapat dilakukan tindakan antisipasi.

Banyak cara dapat dilakukan untuk memprediksi kondisi financial distress perusahaan, salah satunya adalah dengan menganalisa rasio keuangan. Rasio keuangan sebagai indikator dalam menganalisis financial distress telah dikembangkan lebih lanjut menjadi model-model prediksi, diantaranya adalah yang dilakukan oleh Altman (1968, 1983, 1995), Ohlson (1980) dalam Christianti (2013). Springate (1978), Ohlson (1980), Zmijewski (1983) dalam Prihanthini (2013). Di Indonesia, penelitian tentang model prediksi financial distress telah banyak dilakukan, umumnya hanya menggunakan model Altman, sementara model lainnya masih terbatas. Prihanthini (2013) membandingkan model Zmijewski, Altman, dan Springate dalam memprediksi financial distress pada perusahaan yang ada di Bursa Efek Jakarta. Hasilnya model Altman merupakan model prediksi financial distress yang terbaik. Ari Christianti (2013) yang membandingkan model Altman dan Ohlson, yang hasilnya model Ohlson adalah yang terbaik. Lalu ada Ni Made Evi Dwi Prihanthini dan Maria M. Ratna sari (2013) yang membandingkan model Grover, Altman, Springate dan Zmijewski, yang hasilnya model Grover yang terbaik dan sesuai diterapkan di perusahaan $F \& B$ di BEI

\section{KAJIAN TEORI}

Pengertian Financial Distress. Sebelum dinyatakan bangkrut, suatu perusahaan biasanya akan mengalami kondisi financial distresss. Menurut Christianti (2013), prediksi financial distress (kesulitan keuangan) yang akurat menjadi hal yang sangat krusial bagi setiap perusahaan, karena financial distress umumnya dapat mengarah pada kebangkrutan atau kegagalan sebuah perusahaan dan dengan mengetahui tingkat prediksi financial distress, perusahaan dapat segera melakukan tindakan proteksi bisnis lebih baik atau bertindak untuk mengurangi risiko kerugian bisnis atau bahkan menghindarinya.

Banyaknya penelitian membuat munculnya beragam definisi mengenai financial distress. Ross, Westerfield dan Jaffe (2002 : 859) mengemukakan bahwa, "Financial distress is a situation where a firm's operating cash flows are not sufficient to satisfy current obligations (such as trade credits or interest expenses) and the firm is forced to take corrective action.”. Menurut Platt dan Platt (dalam Hidayat dan Meiranto, 2014), financial distress didefinisikan sebagai tahap penurunan kondisi keuangan yang terjadi sebelum kebangkrutan ataupun likuidasi. Platt dan Platt juga menyatakan bahwa kegunaan informasi jika suatu perusahaan mengalami financial distress adalah dapat mempercepat tindakan manajemen untuk mencegah masalah sebelum terjadinya kebangkrutan, pihak manajemen dapat mengambil tindakan merger atau takeover agar perusahaan lebih mampu untuk membayar hutang dan mengelola perusahaan dengan baik serta memberikan tanda peringatan dini/awal adanya kebangkrutan pada masa yang akan datang.

Financial distress menurut Handajani (2013) merupakan suatu kondisi dimana perusahaan mengalami kesulitan dana untuk menutup kewajiban perusahaan atau kesulitan 
likuiditas yaitu jika hutang lebih besar dibandingkan dengan asset. Sedangkan menurut Whitaker (dalam Kurniasari dan Ghozali, 2013), suatu perusahaan dapat dikatakan dalam kondisi financial distress atau kondisi bermasalah apabila perusahaan tersebut mengalami laba bersih (net profit) negatif selama beberapa tahun.

Pengertian Kebangkrutan. Kebangkrutan juga dikenal dengan istilah kepailitan, dan Standars \& Poors (S\&P) (dalam Budiwati, 2011) mengartikan kepailitan sebagai "The first occurrence of a payment default on any financial obligations subject to a bonafide commercial dispute; an exception occurs when an interest payment missed on the due date is made within the grace period". Masih dalam Budiwati (2011), menurut Crouhy, Galai dan Mark, bankruptcy diartikan sebagai sesuatu yang legal atau sebagai suatu peristiwa ekonomi, biasanya ditandai dengan berakhirnya segala bentuk arus kegiatan perusahaan. Peristiwa ini juga merupakan titik akhir dari suatu proses yang panjang, yaitu kondisi perusahaan yang tidak dapat memenuhi kewajiban keuangannya.

Menurut UU nomor 37 tahun 2004 pasal 1 ayat (1) (dalam Nafisatin, Suhadak dan Rustam, 2014), yang dimaksud dengan kepailitan adalah sita umum atas semua kekayaan debitor pailit yang pengurusan dan pemberesannya dilakukan oleh kurator di bawah pengawasan hakim pengawas sebagaimana diatur dalam Undang-Undang ini. Diperjelas pada pasal 2 ayat (1) bahwa apabila debitor yang mempunyai dua atau lebih kreditor dan tidak membayar lunas sedikitnya satu utang yang telah jatuh waktu dan dapat ditagih, dinyatakan pailit dengan putusan pengadilan, baik atas permohonannya sendiri maupun atas permohonan satu atau lebih kreditornya.

Masih dalam Nafisatin, Suhadak dan Rustam (2014), kebangkrutan sebagai suatu kegagalan yang terjadi pada sebuah perusahaan didefinisikan dalam beberapa pengertian, yaitu : a) Kegagalan ekonomi (economic distressed). Kegagalan dalam ekonomi berarti bahwa perusahaan kehilangan uang atau pendapatan, perusahaan tidak mampu menutupi biayanya sendiri, ini berarti tingkat labanya lebih kecil dari biaya modal atau nilai sekarang dari arus kas perusahaan lebih kecil dari kewajiban. Kegagalan terjadi bila arus kas sebenarnya dari perusahaan tersebut jauh di bawah arus kas yang diharapkan. Bahkan kegagalan juga dapat berarti bahwa tingkat pendapatan atas biaya historis dari investasinya lebih kecil daripada biaya modal perusahaan yang dikeluarkan untuk sebuah investasi tersebut, serta b) Kegagalan Keuangan (financial distressed). Pengertian financial distressed mempunyai makna kesulitan dana baik dalam arti dana dalam pengertian kas atau dalam pengertian modal kerja. Sebagian asset liability management sangat berperan dalam pengaturan untuk menjaga agar tidak terkena financial distressed. Kebangkrutan akan cepat terjadi pada perusahaan yang berada di negara yang sedang mengalami kesulitan ekonomi, karena kesulitan ekonomi akan memicu semakin cepatnya kebangkrutan perusahaan yang mungkin tadinya sudah sakit kemudian semakin sakit dan bangkrut.

Model Prediksi Altman (Z-Score). Dalam penelitian Muhammad Nur Rhomadhona (2014) dinyatakan bahwa model ini pertama kali diperkenalkan oleh Edward I. Altman pada tahun 1968. Sampel yang digunakan pada waktu itu mencakup 66 perusahaan yang terdiri dari 33 perusahaan yang bangkrut dan 33 perusahaan yang tidak bangkrut pada tahun 1960-1965. Penelitian yang diterapkan menggunakan Multiple Discriminant Analysis (MDA). Analisis ini merupakan suatu teknik yang mengidentifikasi beberapa 
macam rasio keuangan yang dianggap memiliki nilai penting dalam mempengaruhi suatu kejadian, lalu mengembangkannya ke suatu model. Model persamaan yang diterapkan, yaitu:

$$
Z=1,2 X_{1}+1,4 X_{2}+3,3 X_{3}+0,6 X_{4}+0,999 X_{5}
$$

$\mathrm{X}_{1}$ adalah WCTA, $\mathrm{X}_{2}$ adalah RETA, $\mathrm{X}_{3}$ adalah EBITTA, $\mathrm{X}_{4}$ adalah MVEBVD dan $\mathrm{X}_{5}$ adalah SATA. Kriteria yang digunakan untuk memprediksi kebangkrutan adalah jika nilai $\mathrm{Z}<1$,8; maka perusahaan termasuk perusahaan yang bangkrut, sedangkan apabila nilai $\mathrm{Z}$ antara 1,81 sampai 2,99; maka perusahaan termasuk dalam perusahaan grey area (tidak dapat menentukan apakah perusahaan sehat atau bangkrut). Kemudian jika nilai Z $>$ 2,99 maka perusahaan termasuk perusahaan sehat.

Pada tahun 1984, Altman melakukan revisi persamaan yang telah dibuat sebelumnya yakni pada tahun 1968. Persamaan ini dibuat agar model prediksi ini tidak hanya bisa digunakan pada perusahaan manufaktur yang go public melainkan juga bisa diimplikasikan pada perusahaan swasta. Altman mengembangkan persamaan terbarunya dengan mengganti $\mathrm{X}_{4}$ yang semula nilai pasar modal sendiri terhadap nilai buku hutang menjadi nilai pasar ekuitas terhadap nilai buku hutang. Persamaan hasil revisi terbaru ini yaitu:

$$
Z^{\prime}=0,717 X_{1}+0,847 X_{2}+3,107 X_{3}+0,420 X_{4}+0,998 X_{5}
$$

Kriteria yang digunakan dalam persamaan revisi ini adalah jika nilai $\mathrm{Z}<1,23$ maka perusahaan termasuk perusahaan yang bangkrut, sedangkan apabila nilai Z antara 1,23 sampai 2,9 maka perusahaan termasuk perusahaan grey area (tidak dapat menentukan sehat atau bangkrut). Kemudian apabila nilai $\mathrm{Z}>$ 2,9 maka perusahaan termasuk perusahaan sehat.

Dalam perkembangannya, Altman kemudian memodifikasi modelnya agar persamaan yang telah dia buat dapat digunakan di semua perusahaan. Dalam modifikasi ini, Altman mengeliminasi variabel $\mathrm{X}_{5}$ karena rasio ini sangat bervariatif pada industri dengan ukuran aset yang berbeda-beda. Persamaan model modifikasi ini adalah:

$$
\mathrm{Z}=6,56 \mathrm{X}_{1}+3,26 \mathrm{X}_{2}+6,72 \mathrm{X}_{3}+1,05 \mathrm{X}_{4}
$$

Kriteria untuk persamaan model ini yakni apabila nilai $\mathrm{Z}<1,1$ maka perusahaan termasuk perusahaan yang bangkrut. Jika nilai $\mathrm{Z}$ antara 1,1 sampai 2,6 maka perusahaan termasuk perusahaan grey area (tidak dapat menentukan sehat atau bangkrut) dan apabila nilai $\mathrm{Z}$ $>2,6$ maka termasuk perusahaan sehat.

Model Prediksi Springate. Masih dikutip dari Rhomadhona (2014), bahwa model Springate ini diperkenalkan oleh Gordon L.V. Springate pada tahun 1978. Model ini merupakan pengembangan dari model Altman dan model ini dikembangkan dengan Multiple Discriminant Analysis (MDA). Pada awalnya, model ini menggunakan 19 rasio keuangan yang populer tetapi setelah melakukan pengujian akhirnya Springate memilih 4 rasio yang digunakan untuk menentukan apakah perusahaan termasuk perusahaan yang sehat atau bangkrut. Model ini memiliki keakuratan 92,5\% dengan menggunakan 40 perusahaan sebagai sampel yang digunakan oleh Springate. Persamaan model yang dikemukakan oleh Springate ini adalah: 


$$
S=1,03 A+3,07 B+0,66 C+0,4 D
$$

A adalah WCTA, B adalah EBITTA, C adalah EBTCL, D adalah SATA. Kriteria untuk persamaan model Springate ini adalah jika nilai $\mathrm{Z}<0,862$ maka perusahaan termasuk perusahaan bangkrut dan apabila nilai $\mathrm{Z}>0,862$ maka perusahaan dikategorikan termasuk perusahaan sehat.

Model Prediksi Grover. Dalam penelitian yang dilakukan oleh Prihanthini dan Ratna Sari (2013), disebutkan bahwa model Grover merupakan model yang diciptakan dengan melakukan pendesainan dan penilaian ulang terhadap model Altman Z-Score. Jeffrey S. Grover menggunakan sampel sesuai dengan model Altman Z-score pada tahun 1968, dengan menambahkan tiga belas rasio keuangan baru. Sampel yang digunakan sebanyak 70 perusahaan dengan 35 perusahaan yang bangkrut dan 35 perusahaan yang tidak bangkrut pada tahun 1982 sampai 1996. Jeffrey S. Grover (2001) menghasilkan fungsi sebagai berikut:

$$
\mathrm{G}=1,650 \mathrm{X}_{1}+3,404 \mathrm{X}_{3}-0,016 \mathrm{ROA}+0,057
$$

$\mathrm{X}_{1}$ adalah WCTA, $\mathrm{X}_{3}$ adalah EBITTA, dan ROA adalah NITA. Model Grover mengkategorikan perusahaan dalam keadaan bangkrut dengan skor kurang atau sama dengan $-0,02(Z \leq-0,02)$. Sedangkan nilai untuk perusahaan yang dikategorikan dalam keadaan tidak bangkrut adalah lebih atau sama dengan $0,01(Z \geq 0,01)$.

Model Prediksi Ohlson ( O-Score). Dalam penelitian yang dilakukan oleh Christianti (2013) disebutkan bahwa, berbeda dengan Altman, Ohlson (1980) dalam penelitiannya mengembangkan model logit (multiple logistic regression) untuk membangun model probabilitas kebangkrutan dalam memprediksi kebangkrutan. Ohlson dalam penelitiannya mengklaim bahwa hasil penelitiannya merupakan sebuah penemuan model yang sangat penting. Penemuan penting ini ditunjukkan dari model penelitiannya yang mempertimbangkan sudut pandang kapan perusahaan menerbitkan laporan keuangan kepada publik. Hal ini bertujuan untuk mengontrol apakah perusahaan mengalami kebangkrutan sebelum atau setelah tanggal penerbitan laporan keuangan. Ohlson mengklaim bahwa model sebelumnya tidak mempertimbangkan secara eksplisit masalah waktu penerbitan laporan keuangan.

Ohlson terinspirasi oleh penelitian-penelitian sebelumnya dan melakukan modifikasi atas studinya. Ohlson menggunakan data tahun 1970-1976 dan sampel sebanyak 105 perusahaan yang bangkrut dan 2058 perusahaan yang tidak bangkrut (tidak menggunakan teknik macth-pair sampling). Jika Altman (1968) menggunakan sumber data dari Moody's Manual, maka Ohlson (1980) menggunakan data laporan keuangan yang diterbitkan untuk pajak. Ohlson menggunakan metode statistic conditional logistic. Ohlson berpendapat bahwa metode ini dapat menutupi kekurangan yang terdapat di metode MDA yang digunakan oleh Altman.

Mula-mula Ohlson membangun 3 buah model, dimana setiap model terdiri dari variabel-variabel yang sama. Model yang dibangun Ohlson memiliki 9 variabel yang terdiri dari beberapa rasio keuangan. Berikut ini adalah model Ohlson : 


$$
\begin{gathered}
\mathrm{O}=-1,32-0,407 \mathrm{X}_{1}+6,03 \mathrm{X}_{2}-1,43 \mathrm{X}_{3}+0,0757 \mathrm{X}_{4}-2,37 \mathrm{X}_{5}-1,83 \mathrm{X}_{6}+0,285 \mathrm{X}_{7}- \\
1,72 \mathrm{X}_{8}-0,521 \mathrm{X}_{9}
\end{gathered}
$$

$\mathrm{X}_{1}$ adalah LOGTAGNP, $\mathrm{X}_{2}$ adalah TLTA, $\mathrm{X}_{3}$ adalah WCTA, $\mathrm{X}_{4}$ adalah CLCA, $\mathrm{X}_{5}$ adalah EQNEG, $\mathrm{X}_{6}$ adalah NITA, $\mathrm{X}_{7}$ adalah CFOTL, $\mathrm{X}_{8}$ adalah NINEG, dan $\mathrm{X}_{9}$ adalah DELTANI. Ohlson menyatakan bahwa model ini memiliki cut off point optimal pada nilai 0,38. Ohlson memilih cut off ini karena dengan nilai ini, jumlah error dapat diminimalisasi. Maksud cut off ini adalah bahwa perusahaan yang memiliki skor $\mathrm{O}$ di atas 0,38 berarti perusahaan tersebut diprediksi bangkrut. Sebaliknya, jika skor O di bawah 0,38 maka perusahaan diprediksi tidak mengalami kebangkrutan.

Hipotesis. Hipotesis yang dapat dirumuskan adalah sebagai berikut:

$\mathrm{Ha}_{1} \quad$ : Terdapat perbedaan signifikan antara perusahaan manufaktur yang mengalami financial distress dengan yang tidak mengalami financial distress antara model Altman dengan model Springate.

$\mathrm{Ha}_{2}$ : Terdapat perbedaan signifikan antara perusahaan manufaktur yang mengalami financial distress dengan yang tidak mengalami financial distress antara model Altman dengan model Grover.

Ha3 : Terdapat perbedaan signifikan antara perusahaan manufaktur yang mengalami financial distress dengan yang tidak mengalami financial distress antara model Altman dengan model Ohlson.

$\mathrm{Ha}_{4}$ : Model prediksi financial distress yang paling akurat adalah model Altman.

$\mathrm{Ha}_{5}$ : Model prediksi financial distress yang paling akurat adalah model Springate.

$\mathrm{Ha}_{6} \quad$ : Model prediksi financial distress yang paling akurat adalah model Grover.

$\mathrm{Ha}_{7} \quad$ : Model prediksi financial distress yang paling akurat adalah model Ohlson.

\section{METODE}

Pemilihan Obyek Penelitian. Obyek penelitian ini adalah perusahaan manufaktur yang terdaftar di Bursa Efek Indonesia. Perusahaan yang terdaftar di BEI digunakan karena perusahaan-perusahaan tersebut memiliki kewajiban untuk menyampaikan laporan keuangan tahunan (annual report) kepada pihak eksternal perusahaan, sehingga memungkinkan data tersebut dapat diperoleh dan diakses untuk kepentingan penelitian ini. Periode yang digunakan untuk mengamati dan menganalisis variabel yaitu selama periode 2011-2013.

\section{Metode Penarikan Sampel. Populasi dan Teknik Pengambilan Sampel}

Populasi penelitian ini adalah perusahaan manufaktur yang terdaftar di Bursa Efek Indonesia. Metode pengambilan sampel yang digunakan adalah metode sampel bertujuan (purposive sampling). Metode ini digunakan agar mendapatkan sampel yang representative sesuai dengan pertimbangan dan kriteria yang telah ditentukan. Penarikan sampel ini dilakukan berdasarkan kriteria sebagai berikut : a.) Perusahaan yang bergerak di sektor manufaktur dan listing di Bursa Efek Indonesia selama periode 2011 hingga 2013 secara berturut-turut, b.) Perusahaan yang menerbitkan laporan keuangan (annual report) secara lengkap selama periode 2011-2013, c.) Perusahaan yang menyajikan 
laporan keuangan dalam satuan mata uang rupiah selama periode 2011-2013, d.) Perusahaan yang cut off laporan keuangannya adalah pada tanggal 31 Desember, e.) Perusahaan yang seluruh laporan keuangannya telah diaudit (audited), f.) Perusahaan yang data harga sahamnya tersedia pada tanggal perdagangan terakhir di tahun bersangkutan (closing price).

Perusahaan-perusahaan manufaktur yang dijadikan sampel tersebut akan dikelompokkan menjadi dua kategori, yaitu: 1. Perusahaan yang mengalami financial distress (selanjutnya disebut kategori 1), kriterianya adalah: a) Perusahaan memiliki ekuitas negatif. Ekuitas negatif berarti total utang perusahaan melebihi total asetnya (TL > TA), atau b) Perusahaan memiliki net income negatif selama 2 tahun berturut-turut ; 2. Perusahaan yang tidak mengalami financial distress (selanjutnya disebut kategori 0), kriterianya adalah: a) Tidak memiliki ekuitas negatif dan/atau tidak memiliki net income yang negatif selama 2 tahun berturut-turut, b) Berasal dari tahun dan sektor yang sama dengan sampel kategori 1.

Teknik Pengumpulan Data. Data yang digunakan dalam penelitian ini adalah data sekunder. Data yang diperoleh merupakan data kuantitatif, yaitu data yang berbentuk angka atau data kualitatif yang diangkakan. Teknik-teknik pengumpulan data yang digunakan untuk mendapatkan data yang akurat dan relevan dilakukan dengan metode penelitian kepustakaan. Penelitian kepustakaan dilakukan untuk memperoleh teori yang akurat serta konsep yang kuat dalam penelitian ini. Penelitian kepustakaan dilakukan dengan cara penelaahan artikel, jurnal, text book, situs internet dan sumber-sumber lainnya yang relevan dengan permasalahan yang dibahas.

Teknik Pengolahan Data. Komponen data yang dibutuhkan dari setiap laporan keuangan publikasi , yaitu total assets, total liabilities, earning before tax, earning before interest and tax, earning after tax atau net income tahun berjalan dan tahun sebelumnya (t-1), sales, current assets, current liabilities, retained earning, cash flow from operation, harga saham, jumlah saham beredar dan GNP index.

Kemudian dilakukan perhitungan atas 14 variabel yang telah disebutkan diatas untuk memperoleh score model prediksi. Lalu 14 variabel tersebut dimasukkan ke tiap-tiap rumus dari kelima model prediksi sesuai dengan variabel apa yang dibutuhkan dan akan diperoleh nilai atau score atas tiap-tiap model.

Data score selanjutnya dianalisis dengan statistik untuk dapat menginterpretasikan data dan menarik kesimpulan yang masuk akal (logis) berdasarkan data tersebut. Metode analisis data yang digunakan dalam penelitian ini terdiri dari statistik deskriptif dan uji normalitas data dengan menggunakan SPSS versi 19.00 for Windows.

Teknik Pengujian Hipotesis. Pengujian terhadap setiap hipotesis dilakukan dengan menggunakan uji statistik yang sesuai dengan hipotesis penelitian yang telah ditentukan pada bab sebelumnya. Apabila data terdistribusi secara normal, maka pengujian hipotesis penelitian ini menggunakan teknik analisis perbandingan paired sample t-test. Uji ini merupakan salah satu jenis pengujian beda rata-rata, yaitu menguji apakah ada perbedaan rata-rata antara dua kelompok sampel.

Pengambilan keputusan dalam uji ini adalah berdasarkan perbandingan nilai probabilitas (Sig. 2-tailed). Jika probabilitas (dalam hal ini nilai Sig. 2-tailed) > 0,05, maka 
tidak terdapat perbedaan rata-rata yang signifikan antara dua kelompok sampel. Namun bila probabilitas (dalam hal ini nilai Sig. 2-tailed) $<0,05$, maka terdapat perbedaan ratarata yang signifikan antara dua kelompok sampel. Pengujian dilakukan dengan menggunakan tingkat signifikansi 0,05 (5\%).

Langkah terakhir adalah melakukan uji ketepatan prediksi. Pengujian ini digunakan untuk menghitung estimasi yang benar dan estimasi yang salah atau untuk menguji tingkat keakuratan pengelompokkan dari variabel dependen yaitu kelompok perusahaan yang mengalami kondisi financial distress dan kelompok perusahaan yang tidak mengalami kondisi financial distress.

Selanjutnya adalah membandingkan antara hasil prediksi dan kategori sampel pada seluruh sampel yang ada. Tingkat akurasi menunjukkan berapa persen model memprediksi dengan benar dari keseluruhan sampel yang ada. Tingkat akurasi tiap model dihitung dengan cara sebagai berikut:

\section{Tingkat Akurasi $=($ Jumlah prediksi benar $/$ Jumlah Sampel $) \times 100 \%$}

Selain akurasi tiap model, yang juga menjadi pertimbangan adalah tingkat error-nya. Error dibagi dua jenis, yaitu Type I dan Type II. Type I error adalah kesalahan yang terjadi jika model memprediksi sampel tidak akan mengalami distress padahal kenyataannya mengalami distress. Type II error adalah kesalahan yang terjadi jika model memprediksi sampel mengalami distress padahal kenyataannya tidak mengalami distress. Tingkat error dihitung dengan cara sebagai berikut:

Type I Error = (Jumlah kesalahan Type I / Jumlah Sampel $) \times 100 \%$

Type II Error = $($ Jumlah kesalahan Type II / Jumlah Sampel $) \times 100 \%$

\section{HASIL DAN PEMBAHASAN}

Perhitungan Score Model Prediksi. Setelah memperolah data laporan keuangan perusahaan manufaktur yang terdaftar di Bursa Efek Indonesia dan melakukan seleksi sample sesuai dengan yang telah digambarkan pada Tabel 4.1., maka diperoleh sejumlah keperluan data mentah seperti yang telah disebutkan pada bab 3. Langkah selanjutnya adalah melakukan perhitungan atas nilai score masing-masing model sesuai dengan kriteria rumus yang ada, dengan dibantu program software Microsoft Excel.

Berikut adalah komponen untuk rumus keempat model prediksi, hasil olah data mentah pada perusahaan ADES tahun 2013: WCTA=0,1996 ; TLTA=0,3997 ; RETA=0,7486 ; SATA $=1,1393$; EBITTA $=0,1235$; NITA $=0,1262$; EBTCL $=0,5444$; CLCA $=0,5526$; CFOTL=0,2275 ; DELTANI $=-0,1994 ;$ MVEBVD=6,6925 ; LOGTAGNP=4,0955 ; EQNEG=0 ; NINEG=0. Lalu berikut ini adalah contoh cara menghitung score keempat model untuk perusahaan ADES pada tahun 2013:

\section{Model Altman}

$\mathrm{Z}=1,2 \mathrm{WCTA}+1,4$ RETA + 3,3 EBITTA + 0,6 MVEBVD + 0,999 SATA

$Z=1,2(0,1996)+1,4(-0,7486)+3,3(0,1235)+0,6(6,6925)+0,999(1,1393)$

$\mathrm{Z}=0,2395+(-1,0481)+0,4076+4,0155+1,1382$

$Z=4,7527$ ( $>2,99$; artinya sehat)

\section{Model Springate}

$\mathrm{S}=$ 1,03 WCTA + 3,07 EBITTA + 0,66 EBTCL + 0,4 SATA 
$S=1,03(0,1996)+3,07(0,1235)+0,66(0,5444)+0,4(1,1393)$

$\mathrm{S}=0,2056+0,3792+0,3593+0,4557$

$\mathrm{S}=1,3998$ ( $>0,862$; artinya sehat)

\section{Model Grover}

$\mathrm{G}=1,650$ WCTA $+3,404$ EBITTA $-0,016$ NITA $+0,057$

$\mathrm{G}=1,650(0,1996)+3,404(0,1235)-0,016(0,1262)+0,057$

$\mathrm{G}=0,3293+0,4204-(0,0020)+0,057$

$\mathrm{G}=0,8047$ (>=0,01; artinya sehat)

\section{Model Ohlson}

$\mathrm{O}=-1,32-$ 0,407 LOGTAGNP + 6,03 TLTA - 1,43 WCTA + 0,0757 CLCA - 2,37 EQNEG - 1,83 NITA + 0,285 CFOTL - 1,72 NINEG - 0,521 DELTANI

$\mathrm{O}=-1,32-0,407(4,0955)+6,03(0,3997)-1,43(0,1996)+0,0757(0,5526)-2,37(0)-$ $1,83(0,1262)+0,285(0,2275)-1,72(0)-0,521(-0,1994)$

$\mathrm{O}=-1,32-(1,6669)+2,4101-(0,2854)+0,0418-0-(0,2309)+0,0648-0-(-0,1039)$ $\mathrm{O}=-0,8825(<0,38 ;$ artinya sehat $)$

Hasil perhitungan score untuk keempat model prediksi pada seluruh sampel secara lengkap akan disajikan dalam Lampiran beserta dengan hasil prediksinya berdasarkan nilai cut off masing-masing model. Hasil prediksi akan dibandingkan dengan kondisi perusahaan sebenarnya berdasarkan kriteria perusahaan (kategori 0 atau 1), untuk selanjutnya menentukan model prediksi mana yang memberikan tingkat akurasi yang lebih tinggi.

Statistik Deskriptif. Pada penelitian ini, analisis deskriptif digunakan untuk mengetahui nilai minimum, maximum, mean dan deviasi dari keempat model prediksi financial distress dari perusahaan manufaktur di Bursa Efek Indonesia (BEI) selama periode 2011-2013. Nilai minimum menggambarkan nilai terendah dari sejumlah data/sampel yang dianalisis. Nilai maksimum menggambarkan nilai tertinggi dari sejumlah data/sampel yang dianalisis. Nilai mean menggambarkan nilai rata-rata skor dari data/sampel yang dianalisis.

Standar deviasi menyatakan kecenderungan variasi data/sampel yang dianalisis. Semakin tinggi standar deviasi suatu variabel, maka semakin menyebar data dalam variabel tersebut dari nilai mean nya. Sebaliknya, semakin rendah standar deviasi suatu variabel, maka semakin mengumpul data dalam variabel tersebut pada nilai mean nya. Statistik deskriptif berguna sebagai alat untuk menganalisis data dengan cara menggambarkan sampel yang ada tanpa maksud membuat kesimpulan berlaku umum. Hasil uji statistik deskriptif untuk setiap model dapat dilihat pada tabel 5.1 berikut:

Tabel 1. Statistik Deskriptif Data

\begin{tabular}{lrrrrr}
\hline \multicolumn{7}{c}{ Descriptive Statistics } \\
\hline ALTMAN & N & Minimum & Maximum & \multicolumn{1}{c}{ Mean } & Std. Deviation \\
SPRINGATE & 276 &, 6523 & 2,2767 & 1,164607 &, 1577714 \\
OHLSON & 276 &, 1803 & 1,1685 &, 577054 &, 1503641 \\
Valid N & 276 &, 0362 & 1,6163 &, 562219 &, 2503717 \\
(listwise) & 276 & & & & \\
\hline Sumber: Hasil Pengol & & & & &
\end{tabular}

Sumber: Hasil Pengolahan Data 
Uji Normalitas Kolmogorov Smirnov. Dalam uji normalitas data digunakan uji One Sample Kolmogorov - Smirnov dengan menggunakan taraf signifikansi 0,05. Data dinyatakan berdistribusi normal jika signifikansi lebih besar dari $5 \%$ atau 0,05 . Hasil pengujian normalitas ditunjukkan pada tabel 5.2

Tabel 2. Hasil Pengujian Kolmogorov Smirnov

\begin{tabular}{|c|c|c|c|c|}
\hline \multicolumn{5}{|c|}{ One-Sample Kolmogorov-Smirnov Test } \\
\hline & & ALTMAN & SPRINGATE & OHLSON \\
\hline $\mathrm{N}$ & & 276 & 276 & 276 \\
\hline \multirow[t]{2}{*}{ Normal Parameters ${ }^{\mathrm{a}, \mathrm{b}}$} & Mean & 1,164607 &, 577054 & ,562219 \\
\hline & $\begin{array}{l}\text { Std. } \\
\text { Deviation }\end{array}$ & 1577714 & ,1503641 & ,2503717 \\
\hline Most Extreme & Absolute & ,072 & 057 & ,066 \\
\hline \multirow{2}{*}{ Differences } & Positive & ,072 & 055 & ,066 \\
\hline & Negative &,- 068 &,- 057 &,- 042 \\
\hline Kolmogorov-Smirnov Z & & 1,191 & ,943 & 1,093 \\
\hline Asymp. Sig. (2-tailed) & & ,117 & ,336 & ,183 \\
\hline
\end{tabular}

a. Test distribution is Normal.

b. Calculated from data.

Sumber: Hasil pengolahan data.

Uji Hipotesis Paired Sample T Test. Pengujian hipotesis ini dilakukan untuk mengetahui ada tidaknya perbedaan antara dua sampel dependen berpasangan, yakni apakah terdapat perbedaan signifikan dalam memprediksi financial distress antara model prediksi Altman dengan model prediksi Springate, Grover dan Ohlson. Cara pengambilan keputusannya adalah berdasarkan pada nilai Asymp. Sig. (2-tailed). Jika probabilitas (dalam hal ini nilai Asymp. Sig. 2-tailed) $>0,05$, maka tidak terdapat perbedaan yang signifikan antara dua kelompok sampel. Namun bila probabilitas $<0,05$, maka terdapat perbedaan yang signifikan antara dua kelompok sampel. Berikut adalah hasil output SPSS terhadap pengujian hipotesis paired sample t test.

Tabel 3. Hasil Pengujian Paired Sample T Test

\begin{tabular}{|c|c|c|c|c|c|c|c|c|}
\hline \multicolumn{9}{|c|}{ Paired Samples Test } \\
\hline & \multicolumn{5}{|c|}{ Paired Differences } & \multirow[b]{3}{*}{$\mathrm{t}$} & \multirow[b]{3}{*}{ df } & \\
\hline & \multirow[b]{2}{*}{ Mean } & \multirow{2}{*}{$\begin{array}{c}\text { Std. } \\
\text { Deviation }\end{array}$} & \multirow{2}{*}{$\begin{array}{l}\text { Std. Error } \\
\text { Mean }\end{array}$} & \multicolumn{2}{|c|}{$\begin{array}{c}\text { 95\% Confidence Interval } \\
\text { of the Difference }\end{array}$} & & & $\begin{array}{l}\text { Sig. } \\
(2-\end{array}$ \\
\hline & & & & Lower & Upper & & & tailed) \\
\hline $\begin{array}{ll}\text { Pair } 1 & \text { ALTMAN - } \\
& \text { SPRINGATE }\end{array}$ & ,5875521 & ,2040213 & ,0122806 & ,5633760 & 6117281 & 47,844 & 275 & ,000 \\
\hline
\end{tabular}




\begin{tabular}{llllllllll} 
Pair 2 & ALTMAN - &, 3921967 &, 6005783 &, 0361506 &, 3210297 &, 4633637 & 10,849 & 275 &, 000 \\
& GROVER & & & & & & & & \\
Pair 3 & $\begin{array}{l}\text { ALTMAN - } \\
\text { OHLSON }\end{array}$ &, 6023874 &, 2864044 &, 0172395 &, 5684492 &, 6363256 & 34,942 & 275 &, 000 \\
\hline
\end{tabular}

Sumber: Hasil pengolahan data.

Hasil pada Tabel 3 menunjukkan nilai Sig. (2-tailed) pada pair 1 yakni antara model Altman dan Springate adalah sebesar 0,000. Itu berarti probabilitas < 0,05, yang artinya terdapat perbedaan signifikan antara dua kelompok sampel. Dari hasil tersebut, dapat disimpulkan bahwa $\mathrm{H}_{1}$ diterima, yakni terdapat perbedaan signifikan antara perusahaan manufaktur yang mengalami financial distress dengan yang tidak mengalami financial distress antara model Altman dengan model Springate dengan tingkat keyakinan 95\%.

Hasil pada Tabel 5.3. juga menunjukkan nilai Sig. (2-tailed) pada pair 2 yakni antara model Altman dan Grover adalah sebesar 0,000. Itu berarti probabilitas $<0,05$, yang artinya terdapat perbedaan signifikan antara dua kelompok sampel. Dari hasil tersebut, dapat disimpulkan bahwa $\mathrm{H}_{2}$ diterima, yakni terdapat perbedaan signifikan antara perusahaan manufaktur yang mengalami financial distress dengan yang tidak mengalami financial distress antara model Altman dengan model Grover dengan tingkat keyakinan 95\%.

Demikian halnya pada pair 3 yakni antara model Altman dan Ohlson, juga menunjukkan nilai Sig. (2-tailed) sebesar 0,000. Itu berarti probabilitas $<0,05$, yang artinya terdapat perbedaan signifikan antara dua kelompok sampel. Dari hasil tersebut, dapat disimpulkan bahwa $\mathrm{H}_{3}$ diterima, yakni terdapat perbedaan signifikan antara perusahaan manufaktur yang mengalami financial distress dengan yang tidak mengalami financial distress antara model Altman dengan model Ohlson dengan tingkat keyakinan $95 \%$.

Uji Keakuratan Model Prediksi. Pengujian hipotesis yang terakhir adalah melakukan uji keakuratan model prediksi. Langkah ini dilakukan untuk memperoleh model prediksi yang memiliki tingkat keakuratan paling tinggi serta juga tingkat error yang dihasilkan tiap-tiap model prediksi tersebut. Rumus tingkat akurasi dan tipe error telah dijelaskan dalam bab 3. Selanjutnya, hasil pengujian terhadap ketepatan prediksi akan dibahas satu per satu dan disajikan dalam tabel. Berikut adalah tabel dan penjelasan untuk pengujian keakuratan dan tipe error model Altman, Springate, Grover dan Ohlson.

Tabel 4. Keakuratan Prediksi Model Altman

\begin{tabular}{ccc}
\hline Tahun & Prediksi Benar & Sampel \\
2011 & 80 & 92 \\
2012 & 80 & 92 \\
2013 & 71 & 92 \\
Jumlah & 231 & 276 \\
Tingkat Akurasi & & $83,70 \%$ \\
\hline
\end{tabular}

Sumber: Hasil Pengolahan Data 
Tabel 4 menggambarkan perhitungan secara keseluruhan untuk 276 sampel, yang terdiri dari sampel kategori 0 dan kategori 1 . Dari tabel diatas dapat dilihat bahwa model Altman menghasilkan tingkat akurasi sebesar 83,70\%.

Kemudian untuk pembahasan lebih lanjut, sebanyak total 240 sampel (3 tahun) dalam kategori 0 (non-financial distress), ternyata dari hasil prediksi model Altman, terdapat 200 data sampel yang diprediksi dengan tepat dalam kondisi non-financial distress. Sisanya sebanyak 40 data sampel diprediksi secara tidak tepat yaitu dalam kondisi financial distress.

Lalu untuk kategori 1 (financial distress) yang sebanyak total 36 sampel (3 tahun), ternyata dari hasil prediksi model Altman, terdapat 31 data sampel yang diprediksi dengan tepat dalam kondisi financial distress. Sisanya sebanyak 5 data sampel diprediksi secara tidak tepat yaitu dalam kondisi non-financial distress.

Tabel 5. Tingkat Error Model Altman

\begin{tabular}{ccc}
\hline & Kesalahan Type I & Kesalahan Type II \\
\hline Jumlah & 5 & 40 \\
Jumlah Sample & 36 & 240 \\
Tingkat Error & $13,89 \%$ & $16,67 \%$ \\
\hline
\end{tabular}

Sumber: Hasil Pengolahan Data

Selanjutnya Tabel 5 diatas menunjukkan hasil perhitungan tingkat error pada model Altman. Kesalahan prediksi yang terjadi ada dua, yakni tipe kesalahan pertama dimana perusahaan yang mengalami financial distress dianggap tidak mengalami financial distress dan tipe kesalahan kedua dimana perusahaan yang tidak mengalami financial distress dianggap mengalami financial distress.

Kesalahan tipe pertama pada tahun 2011 adalah sebanyak 1 sampel, tahun 2012 adalah sebanyak 1 sampel dan tahun 2013 adalah sebanyak 3 sampel. Total kesalahan tipe pertama adalah sebanyak 5 sampel dari total 36 sampel. Sehingga tingkat error tipe pertama untuk model Altman adalah sebesar 13,89\%.

Kemudian untuk kesalahan tipe kedua, pada tahun 2011 adalah sebanyak 11 sampel, tahun 2012 juga sebanyak 11 sampel dan tahun 2013 adalah sebanyak 18 sampel. Total kesalahan tipe kedua adalah sebanyak 40 sampel dari total 240 sampel. Sehingga tingkat error tipe kedua untuk model Altman adalah sebesar 16,67\%.

Tabel 6. Keakuratan Prediksi Model Springate

\begin{tabular}{|c|c|c|}
\hline Tahun & Prediksi Benar & Sampel \\
\hline 2011 & 74 & 92 \\
\hline 2012 & 75 & 92 \\
\hline 2013 & 63 & 92 \\
\hline Jumlah & 212 & 276 \\
\hline Tingkat Akurasi & \multicolumn{2}{|c|}{$76,81 \%$} \\
\hline
\end{tabular}

Sumber: Hasil Pengolahan Data

Tabel 6 menggambarkan perhitungan secara keseluruhan untuk 276 sampel, yang terdiri dari sampel kategori 0 dan kategori 1. Dari tabel diatas dapat dilihat bahwa model Springate menghasilkan tingkat akurasi sebesar 76,81\%.Kemudian untuk pembahasan lebih lanjut, sebanyak total 240 sampel (3 tahun) dalam kategori 0 (non-financial distress), ternyata dari hasil prediksi model Springate, terdapat 179 data sampel yang diprediksi 
dengan tepat dalam kondisi non-financial distress. Sisanya sebanyak 61 data sampel diprediksi secara tidak tepat yaitu dalam kondisi financial distress.

Lalu untuk kategori 1 (financial distress) yang sebanyak total 36 sampel (3 tahun), ternyata dari hasil prediksi model Springate, terdapat 33 data sampel yang diprediksi dengan tepat dalam kondisi financial distress. Sisanya sebanyak 3 data sampel diprediksi secara tidak tepat yaitu dalam kondisi non-financial distress.

Tabel 7 diatas menunjukkan hasil perhitungan tingkat error pada model Springate. Kesalahan prediksi yang terjadi yakni tipe kesalahan pertama dimana perusahaan yang mengalami financial distress dianggap tidak mengalami financial distress dan tipe kesalahan kedua dimana perusahaan yang tidak mengalami financial distress dianggap mengalami financial distress. Kesalahan tipe pertama pada tahun 2011 adalah sebanyak 1 sampel, tahun 2012 adalah sebanyak 0 sampel dan tahun 2013 adalah sebanyak 2 sampel. Total kesalahan tipe pertama adalah sebanyak 3 sampel dari total 36 sampel. Sehingga tingkat error tipe pertama untuk model Springate adalah sebesar 8,33\%.

Tabel 7. Tingkat Error Model Springate

\begin{tabular}{|c|c|c|}
\hline & Kesalahan Type I & Kesalahan Type II \\
\hline Jumlah & 3 & 61 \\
\hline Jumlah Sample & 36 & 240 \\
\hline Tingkat Error & $8,33 \%$ & $25,42 \%$ \\
\hline
\end{tabular}

Sumber: Hasil Pengolahan Data

Kemudian untuk kesalahan tipe kedua, pada tahun 2011 adalah sebanyak 17 sampel, tahun 2012 juga sebanyak 17 sampel dan tahun 2013 adalah sebanyak 27 sampel. Total kesalahan tipe kedua adalah sebanyak 61 sampel dari total 240 sampel. Sehingga tingkat error tipe kedua untuk model Springate adalah sebesar 25,42\%.

Tabel 8. Keakuratan Prediksi Model Grover

\begin{tabular}{|c|c|c|}
\hline Tahun & Prediksi Benar & Sampel \\
\hline 2011 & 85 & 92 \\
\hline 2012 & 85 & 92 \\
\hline 2013 & 82 & 92 \\
\hline Jumlah & 252 & 276 \\
\hline Tingkat Akurasi & \multicolumn{2}{|c|}{$91,30 \%$} \\
\hline
\end{tabular}

Sumber: Hasil Pengolahan Data

Tabel 8 menggambarkan perhitungan secara keseluruhan untuk 276 sampel, yang terdiri dari sampel kategori 0 dan kategori 1. Dari tabel diatas dapat dilihat bahwa model Grover menghasilkan tingkat akurasi sebesar 91,30\%. Kemudian sebanyak total 240 sampel (3 tahun) dalam kategori 0 (non-financial distress), ternyata dari hasil prediksi model Grover, terdapat 232 data sampel yang diprediksi dengan tepat dalam kondisi nonfinancial distress. Sisanya sebanyak 8 data sampel diprediksi secara tidak tepat yaitu dalam kondisi financial distress.

Lalu untuk kategori 1 (financial distress) yang sebanyak total 36 sampel (3 tahun), ternyata dari hasil prediksi model Grover, terdapat 20 data sampel yang diprediksi dengan 
tepat dalam kondisi financial distress. Sisanya sebanyak 16 data sampel diprediksi secara tidak tepat yaitu dalam kondisi non-financial distress.

Tabel 9. Tingkat Error Model Grover

\begin{tabular}{ccc}
\hline & Kesalahan Type I & Kesalahan Type II \\
\hline Jumlah & 16 & 8 \\
Jumlah Sample & 36 & 240 \\
Tingkat Error & $44,44 \%$ & $3,33 \%$ \\
\hline
\end{tabular}

Sumber: Hasil Pengolahan Data

Selanjutnya Tabel 9 diatas menunjukkan hasil perhitungan tingkat error pada model Grover. Kesalahan prediksi yang terjadi yakni tipe kesalahan pertama dimana perusahaan yang mengalami financial distress dianggap tidak mengalami financial distress dan tipe kesalahan kedua dimana perusahaan yang tidak mengalami financial distress dianggap mengalami financial distress. Kesalahan tipe pertama pada tahun 2011 adalah sebanyak 5 sampel, tahun 2012 adalah sebanyak 4 sampel dan tahun 2013 adalah yang terbanyak, yaitu 7 sampel. Total kesalahan tipe pertama adalah sebanyak 16 sampel dari total 36 sampel. Sehingga tingkat error tipe pertama untuk model Grover adalah sebesar 44,44\%.

Kemudian untuk kesalahan tipe kedua, pada tahun 2011 adalah sebanyak 2 sampel, tahun 2012 juga sebanyak 3 sampel dan tahun 2013 adalah juga sebanyak 3 sampel. Total kesalahan tipe kedua adalah sebanyak 8 sampel dari total 240 sampel. Sehingga tingkat error tipe kedua untuk model Springate adalah sebesar 3,33\%.

Tabel 10. Keakuratan Prediksi Model Ohlson

\begin{tabular}{ccc}
\hline Tahun & Prediksi Benar & Sampel \\
\hline 2011 & 75 & 92 \\
2012 & 73 & 92 \\
2013 & 67 & 92 \\
Jumlah & 215 & 276 \\
Tingkat Akurasi & & $77,9 \%$ \\
\hline
\end{tabular}

Sumber: Hasil Pengolahan Data

Tabel 10 menggambarkan perhitungan secara keseluruhan untuk 276 sampel, yang terdiri dari sampel kategori 0 dan kategori 1. Dari tabel diatas dapat dilihat bahwa model Ohlson menghasilkan tingkat akurasi sebesar 77,9\%.

Kemudian sebanyak total 240 sampel (3 tahun) dalam kategori 0 (non-financial distress), ternyata dari hasil prediksi model Ohlson, terdapat 199 data sampel yang diprediksi dengan tepat dalam kondisi non-financial distress. Sisanya sebanyak 41 data sampel diprediksi secara tidak tepat yaitu dalam kondisi financial distress.

Lalu untuk kategori 1 (financial distress) yang sebanyak total 36 sampel (3 tahun), ternyata dari hasil prediksi model Ohlson, terdapat 16 data sampel yang diprediksi dengan tepat dalam kondisi financial distress. Sisanya sebanyak 20 data sampel diprediksi secara tidak tepat yaitu dalam kondisi non-financial distress.

Tabel 11. Tingkat Error Model Ohlson 
Hastuti: Analisis Komparasi Model Prediksi Financial Distress Altman Springate...

\begin{tabular}{ccc}
\hline & Kesalahan Type I & Kesalahan Type II \\
\hline Jumlah & 20 & 41 \\
Jumlah Sample & 36 & 240 \\
Tingkat Error & $55,56 \%$ & $17,08 \%$ \\
\hline
\end{tabular}

Sumber: Hasil Pengolahan Data

Selanjutnya Tabel 11 menunjukkan hasil perhitungan tingkat error pada model Ohlson. Kesalahan prediksi yang terjadi yakni tipe kesalahan pertama dimana perusahaan yang mengalami financial distress dianggap tidak mengalami financial distress dan tipe kesalahan kedua dimana perusahaan yang tidak mengalami financial distress dianggap mengalami financial distress.

Kesalahan tipe pertama pada tahun 2011 adalah sebanyak 5 sampel, tahun 2012 adalah sebanyak 6 sampel dan tahun 2013 adalah juga sebanyak 9 sampel. Total kesalahan tipe pertama adalah sebanyak 20 sampel dari total 36 sampel. Sehingga tingkat error tipe pertama untuk model Ohlson adalah sebesar 55,56\%. Kemudian untuk kesalahan tipe kedua, pada tahun 2011 adalah sebanyak 12 sampel, tahun 2012 sebanyak 13 sampel dan tahun 2013 adalah sebanyak 16 sampel. Total kesalahan tipe kedua adalah sebanyak 41 sampel dari total 240 sampel. Sehingga tingkat error tipe kedua untuk model Ohlson adalah sebesar $17,08 \%$.

Berdasarkan hasil analisis dan pembahasan diatas, terlihat bahwa tingkat error tipe 1 model Springate adalah yang paling kecil, dibandingkan dengan ketiga model lainnya, yakni sebesar 8,33\%. Ini artinya, kesalahan prediksi dimana perusahaan yang mengalami financial distress dianggap tidak mengalami financial distress, lebih minim terjadi dalam model prediksi Springate. Hal ini berbanding lurus dengan jumlah prediksi benar model Springate dalam sampel kategori 1 (financial distress), yakni sebanyak 33 sampel dari total 36 sampel. Dengan kata lain, model Springate memiliki tingkat error yang paling rendah dibandingkan ketiga model lainnya dalam memprediksi kondisi financial distress untuk data sampel perusahaan kategori 1.

Sedangkan untuk tingkat error tipe 2, Grover adalah model prediksi yang memiliki nilai paling kecil dibandingkan dengan ketiga model prediksi lainnya, yakni sebesar 3,33\%. Ini artinya, kesalahan prediksi dimana perusahaan yang tidak mengalami financial distress dianggap mengalami financial distress, lebih minim terjadi dalam model prediksi Grover. Hal ini berbanding lurus dengan jumlah prediksi benar model Grover dalam sampel kategori 0 (non-financial distress), yakni sebanyak 232 sampel dari total 240 sampel. Dengan kata lain, model Grover memiliki tingkat error yang paling rendah dibandingkan ketiga model lainnya dalam memprediksi kondisi financial distress untuk data sampel perusahaan kategori 0 .

Selanjutnya, hasil analisis dan pembahasan diatas juga memperlihatkan bahwa berdasarkan perhitungan tingkat keakuratan secara keseluruhan sampel (gabungan antara sampel kategori 0 dan sampel kategori 1), model Altman menghasilkan tingkat keakuratan sebesar 83,7\%, Springate sebesar 76,81\%, Grover sebesar 91,30\% dan Ohlson sebesar $77,9 \%$. Itu artinya, model prediksi yang paling akurat dalam penelitian ini adalah model prediksi Grover dengan persentase sebesar 91,30\%.

Dengan demikian, $\mathrm{H}_{6}$ diterima, yaitu model prediksi financial distress yang paling akurat adalah model Grover. Sedangkan untuk $\mathrm{H}_{4}$, yaitu model prediksi financial distress yang paling akurat adalah model Altman dan $\mathrm{H}_{5}$, yaitu model prediksi financial distress 
yang paling akurat adalah model Springate serta $\mathrm{H}_{7}$, yaitu model prediksi financial distress yang paling akurat adalah model Ohlson, tidak diterima.

Hasil penelitian ini sesuai dan mendukung penelitian yang dilakukan oleh Ni Made Evi Dwi Prihanthini dan Maria M. Ratna sari (2013) yang membandingkan model Grover, Altman, Springate dan Zmijewski, yang hasilnya model Grover juga merupakan model prediksi financial distress yang terbaik. Di sisi lain, hasil penelitian ini tidak sesuai dan tidak mendukung penelitian yang dilakukan Ari Christianti (2013) yang membandingkan model Altman dan Ohlson, yang hasilnya model Ohlson adalah yang terbaik. Serta hasil penelitian ini juga tidak sesuai dan tidak mendukung penelitian yang dilakukan oleh Anggreani (2003) dan Rifqi (2009), yang masing-masing menghasilkan model Altman dan model Springate sebagai model yang terbaik dalam memprediksi financial distress.

\section{PENUTUP}

Simpulan. Setelah melakukan analisis pada bab-bab sebelumnya dengan tujuan untuk mengidentifikasi ada tidaknya perbedaan prediksi antara model Altman dengan model Springate, model Altman dengan model Grover dan model Altman dengan model Ohlson, dimana sampel dibagi menjadi dua kondisi, yaitu financial distress dan non-financial distress, serta mengetahui model yang paling akurat dalam memprediksi kondisi financial distress perusahaan manufaktur yang terdaftar di Bursa Efek Indonesia, telah dihasilkan beberapa kesimpulan, antara lain: (1) Terdapat perbedaan antara model Altman dengan model Springate, model Altman dengan model Grover, dan model Altman dengan model Ohlson dalam memprediksi kebangkrutan pada perusahaan manufaktur yang terdaftar di Bursa Efek Indonesia (BEI) periode 2011-2013, (2) Model Grover merupakan model prediksi yang paling sesuai diterapkan pada perusahaan manufaktur yang terdaftar di Bursa Efek Indonesia (BEI), karena model ini memiliki tingkat keakuratan yang paling tinggi dibandingkan dengan model prediksi lainnya yaitu sebesar 92,03\%. Sedangkan model Altman memiliki tingkat akurasi sebesar 83,7\%, model Springate 76,81\% dan model Ohlson sebesar 77,90\%.

Saran. Dengan mempertimbangkan keterbatasan-keterbatasan penelitian ini, diharapkan penelitian-penelitian yang akan datang dapat menghilangkan keterbatasan-keterbatasan diatas dengan mengikuti saran yang ada, antara lain adalah: (1) Menambah model prediksi yang digunakan menjadi lebih dari empat, (2) Menggunakan model prediksi lainnya yang telah ditemukan seperti Zmijewski, Fuzzy, Beaver, Zavgren atau lain sebagainya, (3) Pada penelitian selanjutnya, disarankan untuk menambah jumlah sampel dan memperlebar lingkup atau periode penelitian, (4) Sebaiknya juga penentuan waktu pengambilan sampel memperhatikan kondisi pasar, apakah pasar sedang mengalami masa-masa krisis atau tidak, apakah kondisi pasar sedang memburuk atau tidak, (5) Menggunakan jenis industri lain yang akan dijadikan sampel, selain manufaktur, (6) Melakukan penelitian terhadap kebangkrutan dengan memperhatikan faktor-faktor lain, seperti harga saham, tingkat inflasi, nilai tukar mata uang dan lain sebagainya.

\section{DAFTAR RUJUKAN}


Budiwati, Hesti. (2011) Analisis Rasio Keuangan Camel Terhadap Prediksi Kepailitan Pada Bank Umum Swasta Nasional Di Indonesia Periode 2004 - 2007. Jurnal WIGA. Vol. 2(2).

Christianti, Ari. (2013) Akurasi Prediksi Financial Distress : Perbandingan Model Altman dan Ohlson. Jurnal Ekonomi dan Bisnis. Vol. 7(2). Hal 77-89.

Ghozali, Imam. (2012) Aplikasi Analisis Multivariate dengan Program IBM SPSS 20. Semarang: Badan Penerbit Universitas Diponegoro.

Handajani, Susana. (2013) Pengaruh Kinerja Keuangan Terhadap Financial Distress Pada Perusahaan Perbankan Di Bei Pada Tahun 2008-2011. Jurnal Akuntansi.

Hartoyo, Nico Tantra. (2013) Prediksi Financial Distress Menggunakan Analisis Diskriminan Pada Perusahaan Manufaktur yang Terdaftar di Bursa Efek Indonesia Tahun 2010-2011. Jurnal Universitas Brawijaya.

Hidayat, M. Arif dan Wahyu Meiranto. (2014) Prediksi Financial Distress Perusahaan Manufaktur di Indonesia. Diponegoro Journal of Accounting. Vol. 3(3). Hal 1-11.

Kurniasari, Christiana dan Imam Ghozali. (2013) Analisis Pengaruh Rasio Camel Dalam Memprediksi Financial Distress Perbankan Indonesia. Diponegoro Journal of Accounting. Vol. 2(4). Hal 1-10.

Nafisatin, Mar'ati , Suhadak dan Rustam Hidayat. (2014) Implementasi Penggunaan Metode Altman (Z-Score) Untuk Menganalisis Estimasi Kebangkrutan (Studi Pada Pt Bursa Efek Indonesia Periode 2011-2013). Jurnal Administrasi Bisnis (JAB). Vol. 10(1).

Prihanthini, N.M. E. Dwi dan Maria M. R. Sari. (2013) Prediksi Kebangkrutan Dengan Model Grover, Altman Z-Score, Springate Dan Zmijewski Pada Perusahaan Food And Beverage Di Bursa Efek Indonesia. E-Jurnal Akuntansi Universitas Udayana 5.2.

Purnajaya, K.D. Methili dan Ni K. Lely A. Merkusiwati (2014) Analisis Komparasi Potensi Kebangkrutan Dengan Metode Z - Score Altman, Springate, Dan Zmijewski Pada Industri Kosmetik Yang Terdaftar Di Bursa Efek Indonesia. EJurnal Akuntansi Universitas Udayana 7.1.

Rhomadhona, M. Nur. (2014). Analisis Perbandingan Kebangkrutan Model Altman, Model Springate, Dan Model Zmijewski Pada Perusahaan Yang Tergabung Dalam Grup Bakrie Yang Terdaftar Di Bursa Efek Indonesia Periode 2010-2012. Jurnal Universitas Negeri Surabaya.

Ross, Stephen A., Westerfield, Randolph W dan Jaffe, Jeffrey F. (2002) Corporate finance sixth edition. United States of America: The McGraw-Hill Companies, Inc.

Syaifudin, M. Naufal. (2013) Perbandingan Analisis Prediksi Kebangkrutan Menggunakan Model Altman Dengan Ukuran Perusahaan Sebagai Variabel Penjelas Pada Perusahaan Industri Keuangan Bank Yang Terdaftar Di Bursa Efek Indonesia Periode 2010-2012. Jurnal Universitas Negeri Surabaya. 